'CENSYRA-SERIDA-Somio, C/ Camino de los Claveles 604, Gijón (Asturias), Spain

'Dpto de Produccion Animal, Facultad de Veterinaria, Madrid, Spain

FELIX GOYACHE' and JUAN P. GUTIERREZ ${ }^{2}$

\title{
Heritability of reproductive traits in Asturiana de los Valles beef cattle breed
}

\begin{abstract}
Summary
Heritability was estimated for four reproductive traits in the Asturiana de los Valles breed in order to evaluate the possibility of include this information in the breed's current improvement program. The estimations were done using an animal model except for calving ease score. For this last trait, a threshold model under a sire model was fitted, with the sire effect as the only random effect in the model besides the residual. Estimated heritabilities for calving interval age at first calving, gestation length, as dam traits, and calving ease were 0.12 , $0.27,0.15$ and 0.42 , respectively. The estimated heritability for calving interval and age at first calving could justify a sire selection program in the Asturiana de los Valles breed taking account their female offsprings' reproductive characteristics. Heritability estimates for gestation length and calving ease suggested a close genetic relationship of these two traits and birth weight. Further research is needed to estimate the genetic (co)variances between these three traits to allow the use of this information in a breed improvement program to reduce dystocia without affecting preweaning growth traits.
\end{abstract}

Key Words: heritability, calving interval, age at first calving, calving ease, gestation length, beef caltle

\section{Zusammenfassung}

Titel der Arbeit: Erblichkeit von Reproduktionsmerkmalen beì der Fleischrindrasse „Asturiana de los Valles"

Es erfolgten Heritabilitätsschătzungen bei vier Reproduktionsmerkmalen von Rindern der Rasse „Asturiana de los Valles". Es sollten die Möglichkeiten einer Verbesserung der Merkmale bei Einbeziehung dieser in ein Zuchtprogramm gepruft werden. Die Schătzungen erfolgten mittels Tiermodell. Die $h^{2}$ Schátzwerte furr die Merkmale Zwischenkalbezeit, Erstkalbealter, Trăchtigkeitsdauer und Kalbeverlauf werden vorgestellt und diskutiert. Sie rechtfertigen die Einbeziehung ausgewăhlier Merkmale in das Zuchtprogramm zur zilichterischen Verbesserung dieser Population. Das gilt besonders fur die Reduzierung von Schwergeburten ohne Einbuße von Wachstumsleistungen.

Schlüsselwörter: Heritabilităt, Zwischenkalbezeit, Erstkalbealter, Kalbeverlauf, Trắchtigkeitsdauer, Fleischrinder

\section{Introduction}

Selective breeding in beef cattle has focused on increase the in animals' growth rates. However, whatever the production system, reproductive traits appear to be the most economically important in a beef cattle improvement program. In fact, reproductive traits dramatically affect productivity. Nevertheless, no suitable selection criterion exists due to the difficulty of finding easily measurable traits under paddock mating (the most frequent case in beef cattle) which are genetically related to reproduction. Asturiana de los Valles is a Spanish beef cattle breed, exploited mostly in traditional and semi extensive conditions in the north of Spain (CAÑON et al., 1994). The presence in the population of a high number of dams presenting the muscular hypertrophy syndrome has increased the breeders interest in maintaining good maternal characteristics. Breeders association (ASEAVA) has defined four major 
reproductive traits: calving interval, age at first calving, gestation length and calving ease.

Calving interval is the chosen trait to measure cows' fertility. Whatever calving date trait (BOURDON and BRINKS, 1982) could be a better measure of fertility because it has a clearer economic significance and higher heritability, this trait have not been selected by ASEAVA. In Asturiana de los Valles breed the calvings are uniformly distributed along year (GOYACHE et al., 1995). In this case, the calving date trait do not show better characteristics than calving interval (MacGREGOR and CASEX, 1998).

The age at first calving is crucial trait for the cow's reproductive performance. There seems to be a high correlation between the age at first calving and the age at subsequent calvings, as well as between the age at calving and the interval between subsequent calvings. In consequence, it does not seem to be possible to compensate late first calving with short intervals between calvings (MICHAUX et al., 1987).

Gestation length has been proposed as a goal to reduce birth weight without affecting preweaning growth traits (BOURDON and BRINKS, 1982). Gestation length is expected to show a high genetic determination with moderate to high heritability (ANDERSEN and PLUM, 1965), and high genetic correlations with birth weight (BOURDON and BRINKS, 1982) and dystocia (NADARAJAH et al., 1989). Gestation length has been included in some sire selection indices (AMER et al., 1998). Calving difficulty affects dramatically economic performance, Distocic calvings influence calf survival, culling and fertility rates, and needing of veterinary assistance (MEIJERING, 1984). It is difficult to estimate the influence of the different environmental and genetic factors on calving ease due to the subjectivity of recording and the lack linear relationship between the effects involved.

It is usually admitted that reproductive traits heritability range between 0.03 and 0.05 (FREEMAN, 1984). Nevertheless, available information is limited and not always can be compared between different production systems: a long time interval is needed to record data and traits included in the breeding goal are not always the same. The objective of this paper is to estimate the genetic parameters for major reproductive traits in the Asturiana de los Valles breed in order to evaluate the possibility of include this information in the current improvement program of the breed.

\section{Material and methods}

The Regional Government of Principado de Asturias, through Asturiana de los Valles Breeders Association (ASEAVA), has implemented performance recording based on nuclei grouping farms according to their proximity and their production system. Only single calving records including calf sex and calving number were considered. Animals with identification errors or ambiguous birth date were eliminated. Those records outside 3.0 standard deviations from the mean values were deleted for calving interval, age at first calving and gestation length.

Calving ease was recorded using BIF Guidelines with the following scores: 1 (no assistance), 2 (minor assistance), 3 (hard assistance), 4 (caesarean section) and 5 (abnormal presentation). Score 5 was not considered for the estimation of the genetic parameters.

Genetic parameters affecting calving interval, age at first calving and gestation length considered as cow traits, were analysed with Meyer's DF-REML program (1991) 
under an animal model. The program has been re-started with different a priori values of the genetic parameters to avoid confusion arising from the possible existence of local maxima. The structure of the data for the three traits is shown in Table 1. The fitted model included four fixed effects for calving interval and gestation length: management group by year of calving as a comparison group, season of calving, calving number and sex of calf. Sex of calf did not show significant influence for age at first calving; in consequence, sex of calf was not included in the fitted model for this trait. The random effects included the additive genetic effect, being their variancecovariance matrix proportional to the additive numerator relationship matrix, and the maternal permanent environment effect for calving interval and gestation length, and the residual.

Table 1

Means, standard deviations, coefficient of variation and structure of available data for the estimation of genetic parameters for calving interval, gestation length and age at first calving in Asturiana de los Valles breed

\begin{tabular}{llll}
\hline Structure of data & $\begin{array}{l}\text { Calving } \\
\text { interval }\end{array}$ & $\begin{array}{l}\text { Age at first } \\
\text { calving }\end{array}$ & $\begin{array}{l}\text { Gestation } \\
\text { length }\end{array}$ \\
\hline Mean (days) & 389.6 & $1,035.0$ & 287.1 \\
Standard deviation & 57.7 & 214.0 & 6.1 \\
Coefficient of variation (\%) & 14.8 & 20.7 & 2.1 \\
Number of animals & 2,488 & 1,673 & 3,296 \\
With record & 1,851 & 1,226 & 2,476 \\
Sires & 137 & 141 & 180 \\
Dams & 500 & 306 & 640 \\
Animals in model & 2,236 & 1,246 & 2,957 \\
Sires with record and offspring & 74 & 20 & 105 \\
Dams with record and offspring & 303 & 25 & 384 \\
Environmental effects & & & 84 \\
$\quad$ Nucleus-year & 113 & 120 & 3 \\
$\quad$ Calving season & 3 & 3 & 4 \\
$\quad$ Calving number & 4 & -1 & 2 \\
\hline Calf sex & 2 & -1 & \\
\hline
\end{tabular}

Table 2 Frequencies of calving ease score and structure of available data for the estimation of genetic parameters for
calving ease in Asturiana de los Valles breed

\begin{tabular}{ll}
\hline No assistance (\%) & 49.7 \\
Minor assistance (\%) & 41.2 \\
Hard assistance (\%) & 7.2 \\
Caesarean section (\%) & 1.9 \\
Number of records & 7,298 \\
Sires with record & 357 \\
Sires without known ancestors & 248 \\
Sires with known father & 141 \\
Sires with father and grandfather known & 35 \\
Environmental effects & 35 \\
$\quad$ Nucleus-year & 123 \\
$\quad$ Calving season & \\
$\quad$ Calving number & 3 \\
\hline
\end{tabular}


Calving ease score is a categorical trait (Table 2), and the usual linear model procedures for estimating heritability would not be appropriate. Consequently, a threshold model under a sire model was fitted to analyse the genetic parameters affecting calving ease. the sire effect was the only random effect in the model besides the residual. The structure of the data prevented the fitting of a sire-maternal grandsire model which would have eliminated $70 \%$ of the dams with record. The runs were carried out with the program written by MISZTAL et al. (1988) that uses an EM algorithm to solve REML. The fitted model included the same four fixed effects described above.

\section{Results and Discussion}

Estimates of the genetic and environmental parameters are shown in Table 3.

Table 3

Estimated parameters and standard errors (below) for caiving interval, age at first calving, gestation length and calving case in the Asturiana de los Valles beef cattle breed

\begin{tabular}{|c|c|c|}
\hline 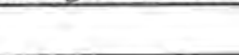 & $h^{2}$ & $c^{2}$ \\
\hline Calving interval & $\begin{array}{l}0.12 \\
0.03\end{array}$ & $\begin{array}{l}0.00 \\
0.03\end{array}$ \\
\hline Age at first calving & $\begin{array}{l}0.27 \\
0.12\end{array}$ & $\cdots$ \\
\hline Gestation length & $\begin{array}{l}0.15 \\
0.03\end{array}$ & $\begin{array}{l}0.01 \\
0.02\end{array}$ \\
\hline Calving ease & 0.42 & $\rightarrow$ \\
\hline
\end{tabular}

Calving interval and age at first calving

Heritability estimates for calving interval and age at first calving in Asturiana de los Valles breed were 0.27 and 0.12 respectively. These estimates are higher than those usually found in literature. Nevertheless, available papers are scarce and usually based on small samples. The mean heritability for calving interval of cows calculated from 4 published papers was 0.10 (KOOTS et al,, 1994). When each of these estimates was weighted by the inverse of its sampling variance, mean heritability was 0.01 . The same authors, from 7 published estimates for heifers, calculated unweighted and weighted heritability means of 0.09 and 0.06 respectively. For age at first calving and 7 published estimates, calculated unweighted and weighted heritability means were 0.14 and 0.06 .

The low heritability estimated for these traits could be explained by: 1) little number of animal available in estimations, 2) the existence of a very important environmental influence on these traits, 3 ) the decrease of genetic variability coming from the culling policy that affects essentially non-regular cows, 4) the need for better adjustment of fixed effects, 5) failure to consider the influence of some other reproductive traits (gestation length or days open) on calving interval and age at first calving, and 6) the use of fitted models that can not explain sufficiently the population structure (HANSET et al., 1989; LOPEZ de TORRE and BRINKS, 1991; REGET and FAMULA, 1993; HAILE-MARIAM and KASSA-MERSHA, 1994).

Asturiana de los Valles breed heritability estimates have been calculated using an animal model. The animal model takes account of every animals' relationships till the 
base population, although it can obtain a better estimate of genetic additive variance. HAILE-MARIAM and KASSA-MERSHA (1994), in Boran cattle exploited in tropical conditions, obtained heritabilities of 0.07 and 0.04 for age at first calving and calving interval respectively using REML under an animal model. BRAGA LOBO (1998) using an animal model in zebu cows estimated a heritability of $0.14 \pm 0.01$ and $0.29 \pm 0.09$ for calving interval and age at first calving respectively. Heritabilities reported for these authors are in close agreement with those estimated in the present paper. On the other hand, there was a relatively large phenotypic variance for both traits in the current database. For calving interval, this situation allow to analyse data from cows that become pregnant 10-11 moths after previous calving. In this conditions is possible to find higher heritability values for reproductive traits (LOPEZ de TORRE and BRINKS, 1991).

\section{Gestation length}

Estimated heritability in Asturiana de los Valles breed for gestation length was 0.15 with a low permanent environmental effect $(0.01)$. This result contrasts with the published range for gestation length heritability of between 0.25 and 0.50 (ANDERSEN and PLUM, 1965). NADARAJAH et al. (1989) in Canadian Holstein cattle and WRAY et al. (1987) in American Simmental cattle estimated direct heritability in 0.33 and 0.374 respectively with a sire-maternal grand sire model. There are no available papers using animal model to estimate genetic parameters of gestation length. Usually, genetic parameters of gestation length have been calculated under a sire or sire-maternal grand sire model (AZZAM and NIELSEN, 1987; NADARAJAH et al., 1989) assuming a non zero covariance between direct and maternal genetic effects. These models could lead to an overestimation of direct and maternal genetic variance if covariance is moderate to high and negative (MEYER, 1994).

In addition, most papers treated gestation length as a calf trait, confounded with birth weight as a genetic character (BOURDON and BRINKS, 1982). Nevertheless, the present results are consistent with those obtained considering gestation length as a dam trait. De FRIES et al. (1959) obtained a heritability of 0.19 with a permanent environment value of 0.02; BOURDON and BRINKS (1982) obtained a gestation length repeatability of 0.20 ; SAPA et al. (1992) found a heritability of 0.21 in Charolais, Limousin and Blond d'Aquitaine heifers maintained in station using a Henderson III method. However, gestation length, as a dam trait, could be related with birth weight maternal genetic effect. GUTIERREZ et al. (1997), fitting different models, reported estimates of maternal genetic effect for birth weight in Asturiana de los Valles breed ranging from 0.09 to 0.20 .

\section{Calving ease}

The calculated heritability for direct genetic effect of calving ease was 0.42 . This result is higher than most previous estimates founded in the literature. According to PHILIPSSON (1979) ranged the heritabilty for calving ease direct genetic effect between $0.03-0.20$ and $0.00-0.08$ for heifers and adult cows. MEIJERING (1984) reported a mean heritability for calving ease in heifers of 0.06 and 0.23 for the observable categorical scale and the underlying normal scale, respectively. The mean values for multiparous cows were 0.075 and 0.21 , respectively. KOOTS et al. (1994), 
reviewing more than 70 published estimates in adult cows, reported a mean heritability for calving ease direct genetic effect of 0.16 . Weighting these estimates by the inverse of their sampling variance, the mean heritability was 0.13 . The calculated unweighted and weighted heritability means for the same trait in heifers were 0.13 and 0.10 respectively. It is not surprising that calculated heritability in the current analysis was higher than values usually found in the literature. Most analysis calculated the calving ease heritability on the observed scale. The usual linear model procedures would underestimate the 'real' heritability on the underlying scale (MEIJERING, 1984; MANFREDI et al., 1991; VARONA et al., 1999).

Nevertheless, the heritability calculated in this analysis could be overestimated. The estimate could be biased by fitting the additive genetic as the only random effect besides the residual. GUTIERREZ et al. (1997) suggested that models which ignore maternal effects tend to overestimate direct heritability. There could be an important maternal genetic effect affecting calving ease. The amount of this maternal genetic effect would be similar than the direct genetic effect. KOOTS et al. (1994) reported a heritability mean value for maternal genetic effect of calving ease ranging 0.09-0.12. VARONA et al. (1999) using a threshold model estimated direct and maternal heritability values of 0.23 and 0.10 respectively. When these authors fitted a linear model, direct and maternal heritability values were of 0.18 and 0.08 respectively. Nevertheless, calving ease would be closely genetically related with birth weight. GUTIERREZ et al. (1997) reported a heritability estimate of 0.37 and 0.57 for birth weight in Asturiana de los Valles breed using a sire and animal model respectively, where a direct genetic effect was the only random effect in model.

\section{Acknowledgements}

This paper has been partially supported by a grant from CICYT-FEDER, no IFD97. 1633 and from Regional Government of Principado de Asturias, Authors would like to thank Mrs. ISABEL GOMEZ for her kind help and comments.

\section{References}

ANDERSEN, H.; PLUM, M.: Gestation lenght and birth weight in cattle and buffaloes: A review. J. Dairy. Sci., Savoy III. 46 (1965),
$1225-1235$

AZZAM, S.M.; NIELSEN, M.K.:

Genetic parameters for gestation lenght, birth date and first breeding date in beef cattle. J. Anim. Sci., Savoy III. 64 (1987), 348-356

BRAGA LÔBO, R.N.:

Genetic parameters for reproductive traits of zebu cows in the semi-arid region of Brazil. Livest. Prod. Sci., Amsterdam SS (1998), 245-248

BOURDON, R.M.; BRINKS, J.S.:

Genetic, environmental and phenotypic relationships among gestation lenght, birth weight, growth traits and age at first calving in beef cattle. J. Anim. Sci., Savoy, III. 55 (1952), 543-553

BRAKEL, W.J.; RIFE, D.C.; SALISBURY, S.M.:

Factors associated with the duration of gestation in dairy cattle. J. Dairy. Sci., Savoy, III. 35 (1952), $179-194$

CAÑÓN, J.; GUTIÉRREZ, J.P.; DUNNER, S.; GOYACHE, F; VALLEJO, M.: Herdbook analyses of the Asturiana beef cattle breeds, Genet. Sel, Evol., Les Ulis 26 (1994), 65-75

DeFRIES, J.C.; TOUCHBERRY, R.W; HAIS, R.L.:

Heritability of the length of the gestation period in dairy cattle. J. Dairy. Sci., Savoy, III. 42 (1959), 598606 
FOOT, W.D.; HAUSER, E.R.; CASIDA, L.E.:

Effect of uterine hom pregnant, parity of dam and sex of calf on birth weight and gestation lenght in FREEMAN A. E.:

Secondary traits: Sire valuation and the reproductive complex.. J. Dairy. Sci, Savoy, III, 67 (1984) $449-458$

GOYACHE, F; GUTIÉRREZ, J.P.; DUNNER, S.; CAÑôN, J.:

Principales efectos ambientales que influyen sobre el intervalo entre partos de la raza Asturiana de los Valles. Arch. Zootec, Córdoba $\$ 4$ (1995), $317-334$

GUTIERREZ, J,P.; CAÑóN, J,; GOYACHE, F.:

Estimation of direct and maternal genetic parameters for preweaning traits in the Asturiana de los Valles beef cattle breed trough animal and sire models. J. Anim. Breed. Genet., Berlin 114 (1997), 261-266

HANSET, R.; MICHAUX, C.; DETAL, G.:

Genetic analysis of some maternal reproductive traits in the Belgian Blue cattle breed. Livest. Prod. Sci., Amsterdam 23 (1989), 79-86

HAILE-MARIAM, H.; KASSA-MERSHA, H.:

Genetic and environmental effects on age at first calving and calving interval of naturally bred Boran (zebu) cows in Ethiopia. Anim. Prod., Haddington 58 (1994), 329-334

IAFFAR, S.M; CHAPMAN, A.B.; CASIDA, L.E.

Causes of variation in lenght of gestation in dairy cattle. J. Anim. Sci., Savoy, III. 9 (1950), 953-1002

KOOTS, K.R.; GIBSON, J.P.; SMITH, C.; WILTON, J.W.:

Analyses of published genetic parameter estimates for beef production traits. 1. Herilability. Anim. Breed. Absir., Wallingdford 62 (1994), 309-338

LÓPEZ de TORRE, G.; BRINKS, J.S.:

Some alternatives to calving date and interval as measures of fertility in beef cattle. $\mathrm{I}$. Anim. Sci. Savoy, III. 68 (1990), 2650-2657

MANFREDI, E.J.; SAN CRISTOBAL, M; FOULLEY, J.L.:

Some factors affecting the estimation of genetic parameters for caltle dystocia under a threshold model. Anim. Prod, Haddington 53 (1991), I51-156

Mac GREGOR, R.G.; CASEY, N.H.:

Evaluation of calving interval and calving date as measures of reproductive performance in a beef breed. Livest. Prod. Sci., Amsterdam 57 (1998), 18I-191

MEIJERING, A.:

Dystocia and stillbirth in cattle. A review of causes, relations and implications. Livest. Prod. Sci., MEYER, K.: Amsterdam 11 (1984), 143-177

MEYER, K.

Estimating variances and covariances for multivariate Animal Models by Restricted Maximum Likelihood. Genet .Sel. Evol., Les Ulis 23 (1991), 67-83

Estimates of direct and maternal correlations among growth traits in Australian beef cattie. Livest. Prod. Sci., Amsterdam 38 (1994), 91-105

MICHAUX, C.; DETAL, G.; HANSET, R.:

Age aux vêlages, intervalles de vêlages et taux de renouvellements a l'intérieur de troupeaux Blanc-Bleu Belge de type viandeux. Ann Méd Vét, Liege 131 (1987), 553-570

MISZTAL, I.; GIANOLA, D.; FOULLEY, J.L.;

Computing aspects of non-linear method of sire evaluation for categorical data. J. Dairy. Sci., Savoy, III. 72 (1989), 1557-1568

NADARAJAH, K.; BURNSIDE, E.B; SCHAEFFER, L.R.:

Factors affecting gestation length in Ontario Holsteins, Can. J. Anim. Sci., Ottawa 69 (1989), 10831086

PHILIPSSON, J.:

Breeding for calving performance. In Calving Problems and Early Viability of the Calf. HOFFMANN, B., MASON, I.L., SCHMIDT, J., Eds. Curr. Top, Vet. Anim. Sci., Elsevier, Amsterdam A (1979), 189. 205

SAPA, J; COMBEAU, H,; MENISSIER, F.:

Variabilité génétique des facilités de vêlage et de leurs composants ches les primipares Charolaises controlées en station. Proceedings of 43a EAAP Anual Meeting, Madrid, Spain, September, 1992, 14. 17 th.

REGET, J.E.O.; FAMULA, T.R.:

Factors affecting calving date and its relationship with production traits of Hereford dams. Anim. Prod., Haddington 57 (1993), 385-395 
VARONA, L., MISZTAL, I., BERTRAND, J.K.:

Threshold-linear versus linear-linear analisys of birth weight and calving ease using an animal model: Variance component estimation. J. Anim. Sci., Savoy, III. 77 (199), 1997-2002

WRAY, N.R.; QUASS, R.L.; POLLACK, E.J.:

Analysis of gestation length in American Simmental cattle. J. Aním. Sci., Savoy, 111, 65 (1987), 970-974

Received: $2000-11-24$

Accepted: 2001-06-29

Authors' addresses

FELIX GOYACHE*, PhD.

CENSYRA-SERIDA

C/ Camino de los Claveles 604

Somió-Gijón, Asturias, E-33203, Spain

E-Mail: felixgg@princast.es

- Corresponding author

Prof. JUAN P.GUTIERREZ, PhD.

Department of Animal Production

Universidad Complutense de Madrid

Facultad de Veterinaria

Madrid, E-28040, Spain 